\title{
Shalat dan Kesehatan Mental dalam Perspektif Buya Hamka
}

Putri Enda Sundari *)

MTsN Dharmasraya, Sumatera Barat, Indonesia E-mail: putrisundari1303@gmail.com

\section{Yusrizal Efendi}

Institut Agama Islam Negeri Batusangkar, Sumatera Barat, Indonesia

E-mail:

yoesefendi@gmail.com
*) Corresponding Author

Kata Kunci: Shalat, Hamka, Kesehatan, Jiwa.
Abstrak: Besarnya pengaruh Shalat bagi jiwa manusia dapat dilihat dari berbagai aspek, namun terkadang banyak orang yang tidak menyadarinya. Jenis penelitian ini merupakan penelitian kepustakaan (library research). Metode analisis yang digunakan dalam penelitian ini adalah metode tafsir tematik atau maudhi' $i$. Sumber data primer dalam penelitian ini adalah ayat-ayat al-Quran yang berkaitan dengan shalat dalam al-Quran menurut Buya Hamka. Hasil penelitian ini adalah secara umum ada tiga pengaruh shalat terhadap kesehatan mental menurut Buya Hakma, yaitu pengaruh shalat terhadap pikiran menurut ulama tafsir ada 2 pertama, pengaruh besar yang dikandung oleh shalat terhadap pikiran (QS. Hud [11]:56), (QS. Ar-Ra`d [13]:22, QS. Al-Isra’ [17]:78) dan kedua, shalat dapat menambah kekuatan jiwa dan meringankan beban yang dipikul (QS. Ar-Ra`d [13]:28 dan QS. An-Nisa [4]:103). Kemudian pengaruh shalat terhadap emosi tafsir ada 2 pertama, membina serta membiasakan jiwa agar terhindar dari sifat tercela (QS. Al-Baqarah [2]:153 dan QS. AlFajr [89]:27-28) dan kedua, membantu manusia dalam menjaga kelangsungan hidup, serta aman dari emosi takut dalam kehidupan. Contohnya takut kepada siksaan Allah (QS. Al-Anfal [8]:2). Selanjutnya pengaruh shalat terhadap spiritual menurut Buya Hamka ada 2 pertama, keutamaan terbesar dalam segi spiritual (QS. Al-Baqarah [2]:45 dan QS. Al-Ma'rij [70]:34-35) dan kedua, shalat sebagai terapi pengobatan yang efektif bagi jiwa (QS. Al-`Ala [87]:15 dan QS. Al-Baqarah [2]:3)

Abstract: The magnitude of the influence of prayer on the human soul can be seen from various aspects. This type of research is library research. The method of analysis used in this research is the thematic interpretation method or maudhi'I. The primary data source in this research is the verses of the Koran related to prayers in the Koran according to Buya Hamka. The results of this study are that in general there are three effects of prayer on mental health according to Buya Hakma, namely the effect of prayer on the mind according to the interpreting scholars, there are two first, the major influence contained by prayer on the mind (QS. Hud [11]: 56), (QS. . Ar-Ra'd [13]: 22, QS. Al-Isra '[17]: 78) and second, prayer can increase the strength of the soul and lighten the burden that should be carried (Surah Ar-Ra'd [13]: 28 and QS. An-Nisa [4]: 103). Then there are 2 effects of prayer on the emotion of interpretation, first, fostering and accustoming the soul to avoid despicable nature (QS. Al-Baqarah [2]: 153 and QS. Al-Fajr [89]: 27-28) and second, helping humans in maintain survival, as well as safe from the emotions of fear in life. For example, fear of Allah's torment (QS. Al-Anfal [8]: 2). Furthermore, according to Buya Hamka, there are 2 effects of prayer on the spiritual first, the greatest virtue in the spiritual aspect (QS. Al-Baqarah [2]: 45 and QS. Al-Ma'rij [70]: 34-35) and second, prayer as a healing effective treatment for the soul (QS. Al-'Ala [87]: 15 and QS. Al-Baqarah [2]: 3) 


\section{PENDAHULUAN}

Manusia diciptakan di muka bumi ini adalah untuk mengabdi, menyembah dan beribadah kepada Allah. Allah telah menyeru hambahamba-Nya kepada agama-Nya yaitu Islam. Menurut al-Quran dan hadis, shalat mempunyai kedudukan yang begitu penting sehingga Allah mengagungkan urusan shalat dari banyak masalah ketaatan di dalam alQuran (Hanbal, 1974, p. 134)

Shalat bukanlah kata-kata baru dalam Islam, bahkan sudah ada semenjak zaman Jahiliah. Shalat artinya doa dan istigfar. Kemudian, kata ini ditempatkan oleh Allah dalam al-Quran menurut makna aslinya. Hal ini terdapat pada beberapa ayat dalam al-Quran, di antaranya QS. Al-Ma'arij [70]:19-23
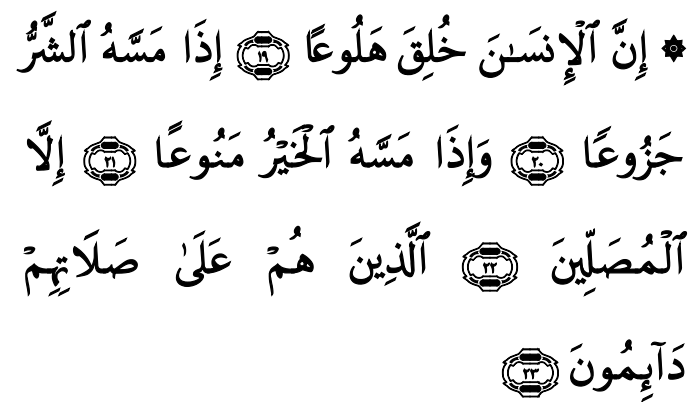

Artinya: Sesungguhnya manusia diciptakan bersifat keluh kesah lagi kikir. Apabila ia ditimpa kesusahan ia berkeluh kesah, dan apabila ia mendapat kebaikan ia amat kikir, kecuali orang-orang yang mengerjakan shalat, yang mereka itu tetap mengerjakan shalatnya.

Shalat adalah pendakian orang beriman serta doa-doa orang shaleh. Shalat memungkinkan akal terhubung secara langsung dengan sang Pencipta, menghindarkan seluruh kepentingan personal dengan material. Hal itu menyelamatkan diri dengan menghancurkan depresi serta menghapus kegelisahan (Baqir, 2003, p. 239).

Shalat adalah media terbesar untuk menghubungkan seorang hamba dengan Tuhannya. Shalat juga menjadi wasilah (perantara) yang sangat penting untuk membentuk tameng agama bagi seorang anak (Mujiburrahman, 2016, vol 6, p.15)

Shalat merupakan ibadah yang istimewa dalam agama Islam, baik yang dilihat dari perintah yang diterima oleh Nabi Muhammad secara langsung dari Tuhan maupun dimensi-dimensi yang lain. (Haryanto, 2007, pp. 60-61). Shalat merupakan salah satu ibadah yang paling mulia dan paling dicintai oleh Allah, bahkan Nabi SAW sendiri telah menegaskan tentang kedudukan shalat dalam agama, yaitu dalam sabda Beliau yang berbunyi "shalat merupakan tiang agama Islam” (HR. 
Ibn Syahin dari Ali). (Jalal S, 2009, p. duduk meletakkan dahinya saat 23)

Allah SWT mewajibkan shalat atas seseorang muslim agar ia taat dan patuh melaksanakannya. Perintah yang diwajibkan pada umumnya lebih mudah dilaksanakan jika jelas tujuan dan manfaat terutama bagi orang yang melaksanakannya. Untuk itu, Allah menetapkan beberapa tujuan di antaranya adalah untuk mengingat Allah jadi substansi shalat adalah mengingat Allah. Namun demikian hati yang selalu ingat kepada Allah, Tuhan yang Maha Sempurna, seseorang akan mendapatkan kekuatan batin ketika menghadapi segala problematika dalam kehidupannya. Hal ini dijelaskan dalam QS. Thaha [20]:14

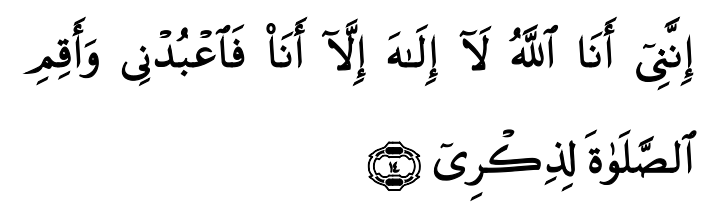

Artinya: Sesungguhnya Aku ini adalah Allah, tidak ada Tuhan (yang hak) selain Aku, maka sembahlah Aku dan dirikanlah shalat untuk mengingat Aku.

Salah satu manfaat shalat adalah terhapusnya dosa-dosa kecil dari catatan amal. Ketika seseorang berdiri dan bertakbiratul ihram untuk melakukan shalat, lalu menundukkan kepalanya untuk melakukan rukuk, lalu bersujud, ia lalu mengulang sujudnya, rukuknya, berdirinya, dan duduknya, maka beban yang berat itu akan jatuh dari bagian paling atas dari kepalanya. Analogi seperti seorang lelaki yang memakai jubah kotor berlumur dosadosa dan noda maksiat yang dilakukannya. Wudhu dan shalatnya yang mencakup ucapan-ucapan dan perilaku-perilaku tertentu, berfungsi untuk membasuh kotoran dan nodanoda itu (Thalba, 2010, p. 171)

Perhatikanlah manfaat-manfaat shalat bagi hati. Bagaimana dengan shalat hati bisa merasakan kebahagiaan dan bersuci. Bagaimana shalat mencegahnya dari kekejian dan kemungkaran, bagaimana apabila seseorang menjadikan shalat sebagai penolongnya di waktu mengalami kesusahan dan kesedihan, dapat menguatkan kesabarannya, melapangkan dadanya, mengobatinya, menghapus nodanya, menghibur dan mengusir kegundahannya. Serta bagaimana shalat dapat membalut luka hatinya, meringankan duka deritanya, memadamkan gejolak emosinya, mengembalikannya kepada mematuhi Tuhannya. Berapa banyak shalat telah 
menghalangiseseorang dari tenggelam di dalam kezhaliman? Berapa banyak dosa? Berapa banyak ia telah menghentikan seseorang dari berlebih lebihan dalam bersenda gurau dan halhal serta hal-hal yang tidak berguna. Berapa banyak shalat telah mengingatkan hati orang mukmin akan Tuhannya, lalu memohon ampun atas dosanya. Sehingga Allah memasukkannya ke dalam golongan orang-orang yang digambarkan Allah (QS. Ali Imran [3]:135)
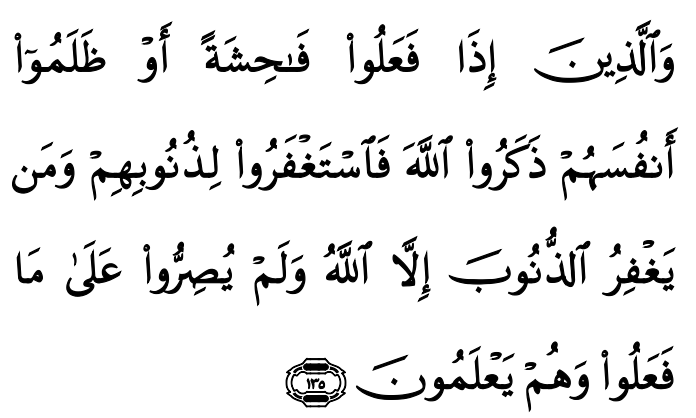

Artinya: Dan (juga) orang-orang yang apabila mengerjakan perbuatan keji atau menganiaya diri sendiri, mereka ingat akan Allah, lalu memohon ampun terhadap dosa-dosa mereka dan siapa lagi yang dapat mengampuni dosa selain dari pada Allah? Dan mereka tidak meneruskan perbuatan kejinya itu, sedang mereka mengetahui (Shiddieqy, 1997, p. 122)

World Healt Organization menyatakan bahwa kesehatan mental merupakan kondisi dari kesejahteraan yang di sadari individu, yang di dalamnya terdapat kemampuan- kemampuan untuk mengelola stres kehidupan yang wajar, untuk bekerja secara produktif dan menghasilkan, sekaligus berperan serta di komunitasnya (Dewi, 2012, pp.10-11).

\section{METODE PENELITIAN}

Dalam penelitian ini, penulis menggunakan jenis penelitian kepustakaan (library research), yaitu teknik pengumpulan data dengan mengadakan studi penelaahan terhadap, buku-buku, literatur-literatur, catatancatatan, dan laporan-laporan yang ada hubungannya dengan masalah yang dipecahkan (Nazir, 2003: 27). Penelitian kepustakaan ini juga disebut dengan serangkaian kegiatan yang berkenaan dengan metode pengumpulan data pustaka, membaca dan mencatat serta mengolah bahan penelitian yang ada di perpustakaan (Zed, 2004, pp. 3-5)

Kajian pustaka memiliki dua makna. Pertama, melalui kajian pustaka peneliti dapat lebih memahami secara teoritis dan konseptual tentang ide-ide pokok penelitian seperti yang tergambar pada pertanyaaan penelitian. Kedua, kajian pustaka dengan menelusuri berbagai teori yang 
berkaitan, pada akhirnya peneliti dapat menemukan teori yang relevan yang selanjutnya dapat di angkat menjadi kajian teori sebagai pijakan dalam penelitan, yang dapat menuntun penulis dalam merumuskan asumsi dasar serta hipotesis penelitian (Sanjaya W. 2014. 205).

Penelitian ini berupa penelitian tafsir. Untuk penelitian kajian al-Quran mengenai pengaruh shalat terhadap kesehatan mental penulis menggunakan metode Tafsir Maudhu'i, yang disebut juga dengan tafsir tematik yaitu penafsiran ayat al-Quran dengan cara menghimpun ayat al-Quran yang memiliki maksud yang sama dalam arti sama-sama membicarakan satu topic masalah, dan menyusunnya berdasarkan kronologi serta sebab turunnya ayat tersebut (al-Farmawi, 1977, p. 36)

\section{HASIL DAN PEMBAHASAN}

\section{Buya Hamka dan Tafsir Al-Azhar}

Buya Hamka lahir di kampung Molek, Maninjau, Sumatera Barat pada tahun 1908 M. Buya Hamka memiliki nama lengkap Haji Abdul Malik Karim Amarullah, tetapi ia lebih popular dipanggil dengan sebutan Hamka yang merupakan singkatan dari namanya. Sebutan Buya biasanya digunakan oleh orang Minangkabau untuk seseorang yang dihormati atau sebutan untuk ayah, yang mana arti dari Buya itu sendiri di Minangkabau adalah ayah kami.

Sebutan Buya terambil dari bahasa Arab yaitu abi atau abuya. Kemudian, ayah Buya Hamka yang dikenal dengan Haji Rasul merupakan seorang pelopor gerakan Islah (reformasi) di Minangkabau sekembali dari Mekah pada 1906 M. Nama lengkap ayahnya adalah Abdul Karim Bin Amarullah. Hamka ketika bocah sering dipanggil dengan Abdul Malik, Hamka mengawali pendidikannya membaca alQuran di rumah orang tuanya ketika mereka sekeluarga pindah dari Maninjau ke Padang Panjang pada tahun 1914 M. Setahun kemudian, setelah mencapai usia 7 tahun, Hamka dimasukkan ayahnya ke sekolah desa (Saifuddin, 2018, p. 101)

Lebih lanjut, pada tahun 1916, Zainuddin Labai mendirikan Sekolah Diniyah petang hari, di Pasar Usang Padang Panjang, Hamka lalu dimasukkan ayahnya ke sekolah ini, pagi hari Hamka pergi ke sekolah desa, 
sore hari pergi belajar ke Sekolah Diniyah dan pada malam hari berada di surau bersama teman-teman sebayanya. Ini adalah rutinitas Hamka di masa kecil. Pendidikan Buya Hamka diawali di sekolah dasar Maninjau hingga tinggkat dua, selanjutnya ia melanjutkan pendidikannya ke Sumatera Thawalib Padang Panjang yang didirikan oleh ayahnya sendiri, saat itu ia berumur 10 tahun. Di situ ia belajar bahasa Arab dan mendaras ilmu-ilmu agama di surau dan masjid yang diasuh sejumlah ulama terkenal seperti Sutan Mansur, RM. Surjoparonto, Ki Bagus Hadikusumo, Syekh Ahmad Rasyid dan Syekh Ibrahim Musa. Hamka memulai pengabdiannya terhadap ilmu pengetahuan dengan menjadi guru agama pada tahun 1927 M di Perkebunan Tebing Tinggi, Medan. Selang dua tahun selanjutnya, $1929 \mathrm{M}$, ia juga menjadi guru di Padang Panjang. Karena karir intelektualnya yang cemerlang, pada tahun 1957 M1958 M, ia dilantik sebagai dosen Universitas Islam Jakarta dan Kebayoran Baru" dengan "Masjid Universitas Muhammadiyah Padang Agung Al-Azhar" oleh Rektor Panjang. Buya Hamka juga pernah Universitas Al-Azhar, Syekh Mahmoud menjabat sebagai Rektor pada Syaltout pada tahun 1960. Hamka
(Saifuddin, 2018, p. 102)

Hamka merupakan seorang yang brilian, kesuksesannya menuntut dan mendapatkan ilmu pengetahuan tidak hanya didapatkan dari pendidikan formal saja, tetapi ia juga belajar secara otodidak, di antaranya ilmu yang beliau pelajari secara otodidak adalah filsafat, satra, sejarah, sosiologi, dan politik, baik Islam maupun Barat.

Buya Hamka aktif dalam organisasi sosial kemasyarakatan di Muhammadiyah hingga ia turut membantu mendeklerasikan berdirinya Muhammadiyah pada tahun 1925 M, ia menjadi Ketua Cabang di Makasar pada 1946 M, ia didaulat sebagai Ketua Majelis Pimpinan Muhammadiyah di Sumatera Barat, ia juga diamanahkan sebagai penasehat pimpinan pusat Muhammadiyah pada tahun $1953 \mathrm{M}$ (Saifuddin, 2018, p. 102)

Di antara karya monumental Hamka adalah Tafsir Al-Azhar. Penamaan Tafsir Al-Azhar tidak terlepas dari penamaan "Masjid Agung Syaltout pada tahun 1960. Hamka 
kuliah Subuh yang disampaikan oleh Hamka di Mesjid Agung Al-Azhar mulai tahun 1959. Pada saat itu Mesjid tersebut belum bernama Al-Azhar. Pada waktu yang bersamaan, Hamka bersama dengan K. H. Fakih Usman dan H. M. Yusuf Ahmad menerbitkan sebuah majalah yang bernama Panji Masyarakat (Malkan, 2019, p. 366)

Karya Hamka pada dasarnya bukan hanya tafsir Al-Azhar saja, ia juga menulis karya-karya yang lain termasuk di bidang sastra, ia menulis buku berjudul "Di bawah Lindungan Ka'bah, Pedoman Mubaligh Islam, Tenggelamnya Kapal Vanderwijk, Tasawuf Modern, Falsafah Hidup, Merantau ke Deli dan Tuan Direktur". Total karyanya lebih dari 115 buah. (Saifuddin, 2018, p. 105)

\section{Shalat}

Shalat secara etimologi adalah doa. Allah berfirman dalam QS. At-Taubah [9]:103
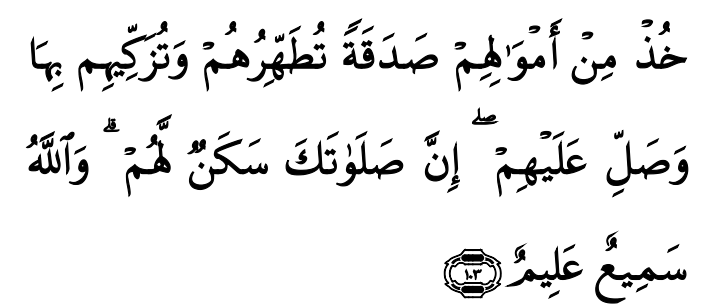

Artinya: Ambillah zakat dari sebagian harta mereka, dengan zakat itu kamu membersihkan dan mensucikan mereka dan mendoalah untuk mereka. Sesungguhnya doa kamu itu (menjadi) ketenteraman jiwa bagi mereka. Dan Allah Maha Mendengar lagi Maha Mengetahui. (Mujiburrahman, 2016, vol 6 p.7)

Arti shalat secara terminologi adalah ucapan dan perbuatan tertentu yang diawali dengan takbir dan diakhiri dengan salam. Dinamakan demikian karena mengandung doa. Orang yang melakukan shalat tidak lepas dari doa, ibadah, pujian dan permintaan. Itulah sebabnya dinamakan shalat (Hawwas, 2013, p. 145)

Shalat menurut terminologi syara adalah beribadah kepada Allah berupa ucapan dan perbuatan secara khusus, yang dimulai dengan takbir dan diakhiri dengan salam. Hal ini dinamakan shalat karena terkandung di dalamnya doa. Sebelumnya shalat adalah nama bagi semua doa. Lalu, kata ini digunakan sebagai nama bagi doa yang dilakukan secara khusus. Dengan kata lain, mulanya ia adalah nama bagi semua doa secara umum, kemudian dibakan menjadi nama bagi shalat secara syar $i$, karena antara shalat dan doa ada keterkaitan. Namun ditinjau lebih cermat, kedua analisa di atas tidak berbeda secara signifikan. Apabila lafaz shalat diucapkan dalam 
terminologi syara, maka tidak ada yang bisa dipahami darinya selain shalat yang disyariatkan (al-Qahtani, 2007, p. 14)

Sedikit berbicara mengenai sejarah shalat bahwa, awalnya shalat hanyalah dua rakaat di waktu sore. Tidak lebih itu, dan tidak pula kurang. Sebgaimana Allah berfirman QS. Al-Mu`min [40]: 55

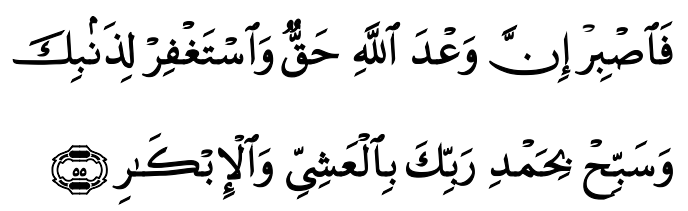

Artinya: Maka bersabarlah kamu, karena sesungguhnya janji Allah itu benar, dan mohonlah ampunan untuk dosamu dan bertasbihlah seraya memuji Tuhanmu pada waktu petang dan pagi.

Tidak beberapa lama sebelum Rasulullah hijrah, Allah mewajibkan shalat lima waktu, dan dilaksanakan oleh segenap kaum muslimin, baik laki-laki maupun perempuan yang telah mencapai usia baligh. Hal ini terjadi pada malam Isra`Mi`raj yaitu kira-kira lima tahun sebelum beliau hijrah ke Madinah (Sati, 2011, pp. 15-16)

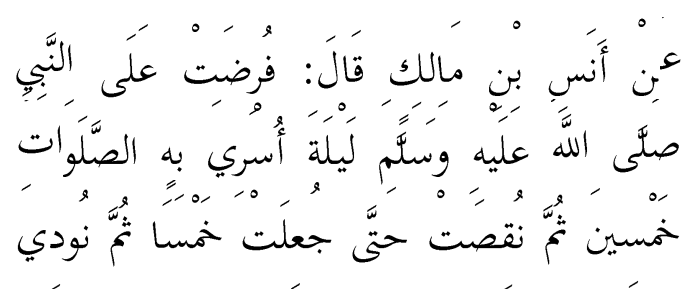

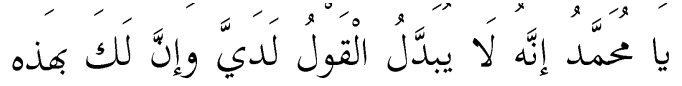

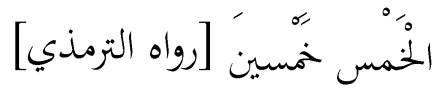

Artinya: Dari Anas bin Malik ia berkata: "Di malam Isra' Nabi shallallahu 'alaihi wa sallam diberi kewajiban untuk melaksanakan shalat sebanyak lima puluh kali. Kemudian bilangan tersebut dikurangi hingga menjadi lima kali, beliau lalu diseru, "Wahai Muhammad, sesungguhnya ketentuan yang ada di sisi-Ku tidak bisa dirubah, maka engkau akan mendapatkan pahala lima puluh (waktu shalat) dengan lima (waktu shalat) ini (HR. al-Turmudzi, 1998, Juz 1, p. 536, hadits 414)

\section{Kesehatan Mental}

\section{Pengertian Kesehatan Mental}

Kesehatan adalah suatu keadaan yang sempurna baik secara fisik, mental dan sosial serta tidak hanya bebas dari penyakit atau kelemahan. Sehat menurut UU 23 tahun 1992 tentang kesehatan adalah keadaan sejahtera dari badan, jiwa dan sosial yang mungkin hidup produktif secara sosial dan ekonomis. Sehat secara mental adalah satu kondisi yang memungkinkan perkembangan fisik, intelektual dan emosional yang optimal dari seseorang dan perkembangan itu berjalan selaras dengan keadaan orangorang lain (Sumiati, 2016, p. 2)

Sehat adalah suatu keadaan sehat secara fisik, mental, dan sosial dimana 
memungkinkan setiap manusia untuk hidup produktif baik secara sosial atau ekonomis. Kondisi sehat dan sakit pada manusia merupakan suatu kontinum, sehingga sangat sulit memberikan batasan yang jelas saat melakukan evaluasinya. Akan tetapi, mengamati fenomena tersebut, maka taraf kesehatan seseorang dapat ditingkatkan bahkan dioptimalkan (Dewi, 2012, p. 10)

Zakiah Darajat (1982, p. 100) mendefenisikan kesehatan mental dengan beberapa pengertian di antaranya adalah terhindarnya orang dari gejala-gejala gangguan jiwa (neurose) dan dari gejala-gejala penyakit jiwa (psychose), kemampuan untuk menyeseuaikan diri dengan diri sendiri, dengan orang lain dan masyarakat serta lingkungan dimana ia hidup, pengetahuan dan perbuatan yang bertujuan untuk mengembangkan dan memanfaatkan segala potensi, bakat dan pembawaan yang ada semaksimal mungkin, sehingga membawa kebahagiaan pada diri dan orang lain serta terhindar dari ganguan-gangguan dan penyakit jiwa, terwujudnya keharmonisan yang sungguh-sungguh antara fungsi-fungsi jiwa, serta mempunyai kesanggupan untuk menghadapi problem-problem biasa yang terjadi, dan merasakan secara positif kebahagiaan dan kemampuan dirinya.

\section{Islam dan Kesehatan Mental Manusia}

Kesehatan mental adalah kondisi dimana seseorang individu dapat berkembang secara fisik, mental, spiritual dan sosial sehingga individu tersebut menyadari kemampuan sendiri, dapat mengatasi tekanan, dapat bekerja secra produktif, dan mampu memberikan kontribusi untuk komunitasnya (Fitriasari, 2019, p. 2).

Perubahan-perubahan sosial yang begitu cepat akibat modernisasi, dapat menyebabkan masyarakat kehilangan identitas diri, sehingga masyarakat modern sangat mudah terserang penyakit stres, depresi dan kecemasan. Pada sisi lain, kemajuan sains dan teknologi sebagai tulang punggung modernisasi, tanpa disadari telah terjadi penyalahgunaannya, sehingga mengakibatkan dampak negatif berupa kerusakan lingkungan hidup, polusi, perambahan hutan, dan berbagai macam kerusakan alam lainnya (Thaib, 2006, p. 174). 
Gangguan-gangguan kejiwaan bisa timbul karena bermacam-macam faktor, baik dari dalam diri sendiri maupun dari luar diri seseorang. Ketidak mampuan seseorang menghadapi segala macam problem kehidupan akan mengiringinya ke jalan hidup yang tidak stabil, mudah mengalami goncangan. Karena itulah penyakit stress menghinggapi manusia dengan beberapa tahapan, dari tahapan ringan hingga tahapan paling berat dan kronis (Jauhari, 2011, p. 37)

\section{Ibadah dan Kesehatan Mental}

Dalam Islam terdapat perintah untuk beribadah tidak lain untuk kemaslahatan setiap muslim itu sendiri. Seseorang muslim yang selalu beribadah berarti ingin selalu dekat dengan Tuhannya di kala suka dan duka, karena Allah tempat manusia bersyukur dan meminta kepada-Nya mereka meminta pertolongan. Jika seseorang tekun mendirikan shalat dengan benar, maka ia selalu diingat oleh Allah, dengan shalat seseorang akan mendapatkan ketenangan hati dan jiwa karena merasa terlindungi dari segala macam cobaan. Seseorang merasa terjaga meski tidak ada seseorang pun yang menjaganya (Jauhari, 2011, p. 41)

Menurut M. Quraish Shihab (1994, p. 162) di sini shalat telah menjadi kebutuhan bukan nya beban atau kewajiban. Shalat menggambarkan pemahaman seseorang menyangkut tata kerja alam raya ini yang memberikan ketenangan dan kemantapan kepada manusia. Karena manusia adalah makhluk yang memiliki naluri cemas dan mengharap. Ia selalu membutuhkan sandaran, terutama pada saat-saat cemas ketika berharap. Kenyataan sehari-hari membuktikan bersandar pada makhluk, betapapun tinggi kekuatan dan kekuasaannya, seringkali tidak membuahkan hasil. Yang mampu hanyalah Tuhan semata

Menurut ilmu mental agama, pada saat seseorang shalat dengan khusyu', seluruh alam pikiran dan perasaannya akan terlepas dari semua urusan dunia yang membuat dirinya terganggu jiwanya tenang dan merasa damai dalam hati. Jika hidup ini terus menerus diporsi untuk mencari harta dan karir, maka waktu yang 24 jam sehari semalam terasa tidak cukup (Jauhari, 2011, p. 41) 
World healt organization, menurut ilmu psikologi, qalb adalah menyatakan bahwa kesehatan mental segumpal daging atau sesuatu yang merupakan kondisi dari kesejahteraan dapat membalik atau berbolak balik. yang di sadari individu, yang di Qalb ini berpotensi tidak konsisten aldalamnya terdapat kemampuan- Quran pun menggambarkan demikian kemampuan untuk mengelola stres ada yang baik dan ada pula yang buruk kehidupan yang wajar, untuk bekerja (Napitupulu, 2019, vol 4, p. 63) secara produktif dan menghasilkan, Ketiga, spiritual berasal dar kata spirit sekaligus berperan serta di yang berarti semangat, jiwa, roh, komunitasnya. (Dewi, 2012, pp.10-11) mental, batin, rohani dan keagamaan.

Adapun secara umum komponen (Anshori, 1995, p. 653) spiritual sama kesehatan mental menurut Prof. Dr. M. halnya dengan ruh, yang mana ruh Noor Rochman Hadjam, S.U, yaitu: adalah al-nafs yaitu jiwa manusia. Hal pertama pikiran, yaitu proses yang ini ditandai dengan ditiupkannya ruh mempengaruhi penafsiran terhadap kepada manusia, maka manusia ransangan-ransangan seperti proses menjadi makhluk yang istimewa dan sensasi, persepsi, dan memori (Kholis, unik serta berbeda dengan makhluk 2014, p. 12) dalam hal ini pikiran sama lainnya. (Astuti, 1982, vol 7 p. 217) halnya dengan aql, aql atau akal adalah Allah berfirman dalam QS. Al-Hijr sebagai daya untuk memperoleh [15]: 29

pengetahuan. Akal juga mempunyai daya untuk mengabstraksikan bendabenda yang ditangkap panca indera (Napitupulu, 2019, vol 4, p. 58) Kedua, emosional adalah suatu keadaan yang komplek dari organisme seperti terganggunya perasaan yang

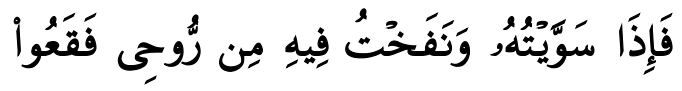

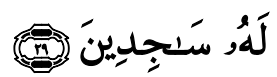

Artinya: Maka apabila Aku telah menyempurnakan kejadiannya, dan telah meniup kan kedalamnya ruh (ciptaan)-Ku, maka tunduklah kamu kepadanya dengan bersujud

disertai dengan perubahan-perubahan dalam organ tubuh yang sifatnya luas (Sudarsono, 1993, p. 32) dalam hal ini emosional dikaitkan dengan qalb yaitu 
Pengaruh Shalat Terhadap Pikiran Ayat dan Terjemahan

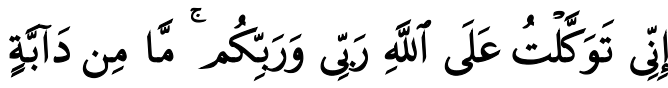

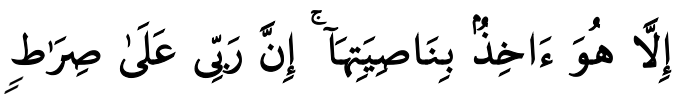

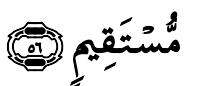

Artinya: Sesungguhnya aku bertawakkal kepada Allah Tuhanku dan Tuhanmu. tidak ada suatu binatang melata pun melainkan Dialah yang memegang ubun-ubunnya. Sesungguhnya Tuhanku di atas jalan yang lurus (QS. Hud [11]:56)

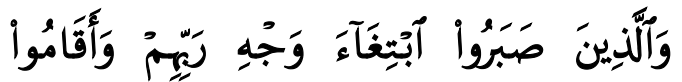

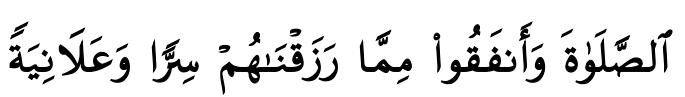

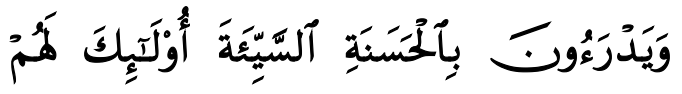

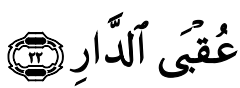

Artinya: Dan orang-orang yang sabar karena mencari keridhaan Tuhannya, mendirikan shalat, dan menafkahkan sebagian rezki yang kami berikan kepada mereka, secara sembunyi atau terang-terangan serta menolak kejahatan dengan kebaikan, orangorang itulah yang mendapat tempat kesudahan (yang baik) (QS. Ar-Ra'd [13]:22)
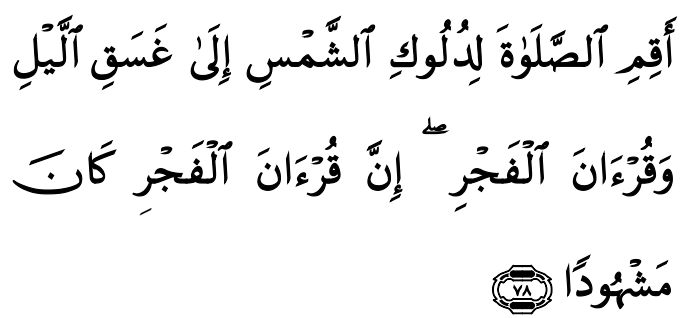

Artinya: Dirikanlah shalat dari sesudah matahari tergelincir sampai gelap malam dan (dirikanlah pula shalat) subuh. sesungguhnya shalat subuh itu disaksikan (oleh malaikat). (QS. Al-Isra` [17]:78)

\section{Tafsiran Ayat}

Hamka dalam kitabnya Tafsir AlAzhar (2015, jilid 4, p. 570) menafsirkan QS. Hud [11]:56 bahwa ucapan ini adalah puncak tauhid sejati. Aku bertawakal kepada Allahku! Dan dia pun Allah kamu juga pada hakikatnya jika kepada-Nya aku bertawakal, Dialah yang akan melindungiku dari gangguan mereka karena mereka pun makhluk-Nya, "Tidak ada satupun yang melata" di muka bumi ini yang merangkak atau menjalar, Pendeknya segala yang bernyawa termasuk aku dan kalian, "Melainkan Dialah yang menguasai ubun-ubunnya”.

Di ayat ini disebut nashiyah yang berarti ubun-ubun. Maka ubun-ubun itulah yang dikuasai dan dipegang oleh Allah sehingga tidak satu pun yang melata di atas bumi yang sanggup keluar dari apa yang telah ditentukan oleh Allah.

Menurut analisa penulis, pada QS. Hud [11]:56 menjelaskan bahwa shalat merupakan informasi yang masuk ke dalam sel otak sebanyak lima kali 
sehari. Informasi ini berfungsi untuk memperbaiki gangguan yang terjadi pada program yang ada dalam otak. Jadi, ubun-ubun merupakan bagian otak yang terpenting, karena otak bekerja saat seseorang memusatkan konsentrasi kepada sesuatu atau berusaha menyelesaikan suatu persoalan. Oleh sebab itu, ayat ini menginformasikan kepada seseorang untuk menjaga shalat lima waktu sehari semalam.

Hamka dalam kitabnya Tafsir AlAzhar (2015, jilid 3, p. 319) menafsirkan QS. Ar-Ra`d [13]:22 bahwa tegasnya dirikanlah shalat lima waktu. Dirikanlah shalat sejak tergelincir matahari dari pertengahan siang, yaitu permulaan waktu Zuhur, dan matahari itu setelah tergelincir di tengah hari dari pertengahan siang akan terus condong ke barat sampai dia terbenam. Oleh sebab itu, dalam kata tergelincir matahari termasuklah Zuhur dan Ashar, sampai kegelap gulita malam. Artinya, apabila matahari telah terbenam ke ufuk barat, artinya mulailah hari malam, dan di permulaan malam itu datanglah waktu Magrib. Bertambah matahari terbenam ke balik bumi hilanglah syafaq yang merah.
Yaitu, garis merah di ujung langit sebelah barat sejak matahari terbenam, dan garis merah itupun hilanglah bila matahari bertambah terbenam tersorok ke balik belahan bumi, maka masuklah Isya.

Lebih lanjut Hamka dalam kitabnya Tafsir Al-Azhar (2015, jilid 3, p. 319) menafsirkan QS. Ar-Ra`d [13]:22 bahwa Imam Malik di dalam kita al-Muwathta, apabila Syafaq merah itu tidak ada lagi, keluarlah engkau dari waktu Magrib dan masuklah ke waktu Isya. Kemudian disebutkanlah al-Quran fajri, yang artinya ialah al-Quran di waktu fajar, tetapi tafsirnya ialah shalat Subuh. Dengan pemakaian kata Quran untuk shalat Subuh ini dapat dipahamkan bahwa yang shalat itu ialah bacaan.

Menurut analisa penulis, QS. ArRa`d [13]:22 menjelaskan bahwa apabila seseorang ingin mengharapkan keridhaan Tuhannya, maka seseorang haruslah bersabar. Sabar dari segi ketaatan dan maksiat serta melaksanakan shalat, menginfakkan rezeki yang diberikan Allah kepadanya. Hamka dalam kitabnya Tafsir AlAzhar (2015, jilid 3, p. 319) menafsirkan QS. Al-Isra` [17]:78 
bahwa tegasnya dirikanlah shalat lima waktu. Dirikanlah shalat sejak tergelincir matahari dari pertengahan siang, yaitu permulaan waktu Zuhur, dan matahari itu setelah tergelincir di tengah hari dari pertengahan siang akan terus condong ke barat sampai dia terbenam. Oleh sebab itu, dalam kata tergelincir matahari termasuklah Zuhur dan Ashar, sampai ke gelap-gulita malam. Artinya, apabila matahari telah terbenam ke ufuk barat, artinya mulailah hari malam, dan di permulaan malam itu datanglah waktu Magrib. Bertambahlah matahari terbenam ke balik bumi hilanglah syafaq yang merah, yaitu garis merah di ujung langit sebelah barat. Sejak matahari terbenam, dan garis merah itupun hilanglah bila matahari bertambah terbenam tersorok ke balik belahan bumi, maka masuklah Isya.

Lebih lanjut Hamka dalam kitabnya Tafsir Al-Azhar (2015, jilid 1, p. 299) menafsirkan QS. Al-Isra' [17]:78 bahwa Imam Malik di dalam kitab Al-Muwathta, "apabila syafaq merah itu tidak ada lagi, keluarlah engkau dari waktu Magrib dan masuklah ke waktu Isya. Kemudian disebutkanlah Quranul Fajri, yang arti harfiahnya ialah Quran di waktu fajar, tetapi tafsirnya ialah shalat Subuh. Mengapa shalat Subuh itu disebutkan Quranul Fajri? Karena, di waktu Subuh hening pagi itu dianjurkan membaca ayat-ayat al-Quran agak panjang dari pada waktu yang lain. Kemudian, pada waktu Subuh itu datanglah waktu bergiliran di antara malaikat pengawal siang yang baru datang, berkumpul dengan malaikatmalaikat pengawal malam yang akan pergi. Laksana pergantian aplusan piket-piket tentara layaknya.

Menurut analisa penulis, QS. AlIsra` [17]:78 menjelaskan bahwa kewajiban seseorang untuk shalat lima waktu sehari semalam yaitu (Subuh, Zuhur, Ashar, Magrib, Isya) mulai tergelincir matahari sampai larut malam dan Subuh. Ayat ini juga menginformasikan tentang apabila seseorang melaksanakan shalat Subuh, maka malaikat akan menyaksikan seseorang tersebut.

Shalat Dapat Menambah Kekuatan Jiwa dan Meringankan Beban yang Dipikul Ayat dan Terjemahan

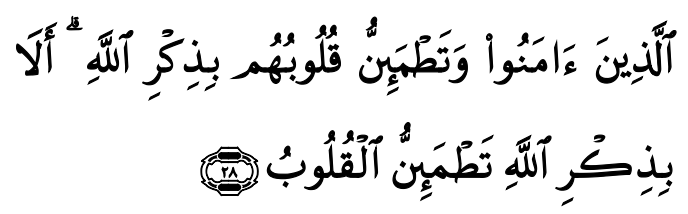


Artinya: Yaitu orang-orang yang beriman dan hati mereka menjadi tentram dengan mengingat Allah, ingatlah hanya dengan mengingat Allahlah hati menjadi tentram (QS. ArRa'du [13]:28)
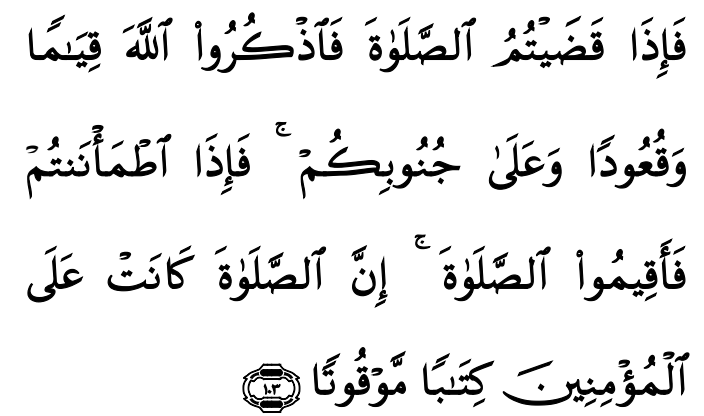

Artinya: Maka apabila kamu telah menyelesaikan shalat(mu), ingatlah Allah di waktu berdiri, di waktu duduk dan di waktu berbaring. Kemudian apabila kamu telah merasa aman, maka dirikanlah shalat itu (sebagaimana biasa). Sesungguhnya shalat itu adalah fardhu yang ditentukan waktunya atas orang-orang yang beriman (QS. An-Nisa[4]:103)

\section{Tafsiran Ayat}

Hamka dalam kitabnya Tafsir AlAzhar (2015, jilid 2, p. 69) menafsirkan QS. Ar-Ra'du [13]:28 bahwa iman adalah menyebabkan senantiasa ingat kepada Allah atau zikir. Iman menyebabkan hati seseorang mempunyai pusat ingatan atau tujuan ingatan, dan ingatan kepada Allah itu menimbulkan tentram, dan dengan sendirinya hilanglah segala macam kegelisahan, pikiran kusut, putus asa, ketakutan, kecemasan, keragu-raguan dan duka cita. Ketentraman hati adalah pokok kesehatan rohani dan jasmani. Ragu dan gelisah adalah pangkal segala penyakit. Orang lain kurang sekali dapat menolong orang yang meracun hatinya sendiri dengan kegelisahan. Kalau hati telah ditumbuhi penyakit, dan tidak segera diobati dengan iman, yaitu iman yang menimbulkan zikir, dan zikir yang menimbulkan thuma'ninah, maka celakalah yang akan menimpa, hati yang telah sakit akan bertambah sakit, dan puncak segala penyakit hati ialah kufur akan nikmat Allah.

Lebih lanjut Hamka dalam kitabnya Tafsir Al-Azhar (2015, jilid 2, p. 70) menafsirkan QS. Ar-Ra'du [13]:28 bahwa al-Quran telah membagi-bagi tingkat pengalaman nafsu kepada tiga, yaitu pertama, $A n$ Nafsul Ammarah Bissu', QS. Yusuf [12]:53 yaitu nafsu yang selalu menyuruh dan mendorong supaya berbuat yang jahat. Karena, nafsu yang demikian yang dapat ditunggangi oleh setan, tetapi apabila terlanjur timbullah nafsu kedua, yaitu Nafsul Lawwamah, QS. Al-Qiyamah [75]:2 yaitu tekanan batin dan penyesalan karena terlanjur. Kelak, karena pengalaman-pengalaman diri, karena memperturutkan An-Nafsul 
Ammarah Bissu', yang menimbulkan sesal Nafsul Lawwamah, bagi orang yang mengambil pengalaman dari beberapa kegagalan. Ketiga, An-Nafsul Muthmainnah, QS. Al-Fajr [89]:27 yaitu nafsu yang telah mencapai ketentramannya, setelah menempuh berbagai pengalaman. Disinilah perlunya iman dan zikir, sehingga berpadulah kehendak hati sanubari yang bersih dengan dorongan nafsu, guna mencapai ridha Allah dengan ketentraman itu.

Menurut analisa penulis, QS. ArRa'du [13]:28 ini menjelaskan bahwa apabila hati ingin tentram, maka ingatlah kepada Allah, dimanapun berada. Baik di waktu pagi, siang, malam. Karena, bimbingan Allah kepada makhluk-Nya sangat erat. Ayat ini juga menginformasikan tentang hanya dengan berzikir mengingat Allah hati menjadi tentram dan seberat apapun beban yang dipikul akan terasa ringan.

Hamka dalam kitabnya Tafsir AlAzhar (2015, jilid 1, p. 435) menafsirkan QS. An-Nisa` [4]:103 bahwa kerjakanlah shalat itu menurut rukunnya, di dalam waktunya, dan lebih utama lagi di awal waktunya. Dalam susunan ayat ini bahwa shalat perang atau shalatul khauf selain dari makmum dibagi menjadi beberapa golongan. Yaitu, segolongan shalat satu rakaat, dan hanya imam yang dua rakaat, adalah bahwa shalat ini tidak diulang legi kelak, tidak ada qada'. Jadi shalat dapat disimpulkan bahwa bagaimanapun berkecamuknya peperangan, namun shalat tidaklah boleh ditinggalkan. Sebab shalat adalah tiang dari kehidupan muslim.

Menurut analisa penulis, QS. AnNisa` [4]:103 ayat ini menjelaskan bahwa dimana Allah memerintahkan umat manusia untuk senantiasa tunduk kepada-Nya melalui shalat. Ayat ini juga menegaskan bahwa shalat adalah wajib bagi setiap orang-orang yang beriman, ayat ini juga menginformasikan tentang apabila seseorang telah selesai shalat, maka seseorang disuruh untuk selalu mengingat Allah. Baik ketika duduk, berdiri maupun berbaring.

\section{Pengaruh Shalat Terhadap Emosional Membina Serta Membiasakan Jiwa Agar Terhindar dari Sifat Tercela}

Ayat dan Terjemahan

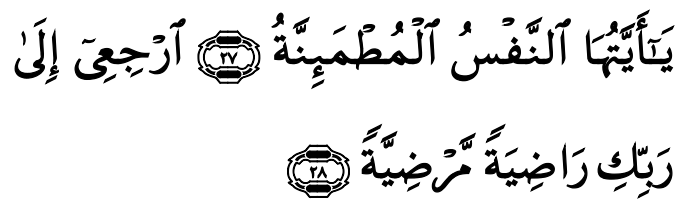

Artinya: Hai jiwa yang tenang. Kembalilah kepada Tuhanmu dengan 
hati yang puas lagi diridhai-Nya. (QS. Al-Fajr [89]:27-28)

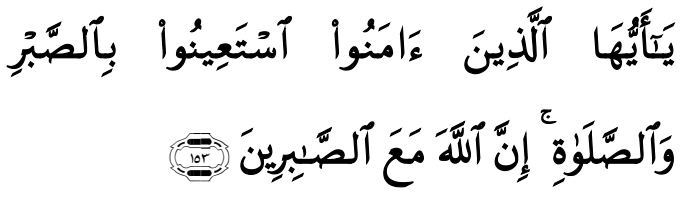

Artinya: Hai orang-orang yang beriman, jadikanlah sabar dan shalat sebagai penolongmu, sesungguhnya Allah beserta orang-orang yang sabar. (QS. Al-Baqarah [2]:153)

\section{Tafsiran Ayat}

Hamka dalam kitabnya Tafsir AlAzhar (2015, jilid 9, p. 577) menafsirkan QS. Al-Fajr [89]:27-28 bahwa yang telah menyerah penuh dan tawakal kepada Tuhannya, telah tenang karena telah mencapai yakin kepada Allah. Berkata Ibnu Atha "yaitu jiwa yang telah mencapai makrifat sehingga tidak sabar lagibercerai dari Tuhannya walau sekejap mata". Allah itu senantiasa tetap dalam ingatannya. Berkata Hasan Al-Bishri tentang Muthmainnah ini "apabila Allah berkehendak mengambil nyawa hamba-Nya yang beriman, tentramlah jiwanya terhadap Allah dan tentram pula Allah terhadapnya".

Lebih lanjut Hamka dalam kitabnya Tafsir Al-Azhar (2015, jilid 9, p. 578) menafsirkan QS. Al-Fajr [89]:27-28 bahwa artinya setelah payah engkau dalam perjuangan hidup di dunia fana, sekarang pulanglah engkau kembali kepada Tuhanmu, dalam perasaan sangat lega karena ridha dan Allah pun ridha karena telah menyaksikan sendiri kepatuhanmu kepda-Nya dan tidak pernah mengeluh.

Menurut analisa penulis, QS. AlFajr [89]:27-28 ini menjelaskan bahwa muthmainnah adalah ketenangan sebagai kesimpulan yang dihasilkan dari keimanan kapada Allah, meyakinkan hati akan keEsaan-Nya yang bisa dilakukan dengan perentara berzikir atau mengingat dan menyebut nama Allah. Sehingga bisa mengantarkan seseorang pada derajat untuk ikhlas dan ridho atas apapun yang telah Allah tentukan dan takdirkan baik maupun buruk. Ayat ini juga menginformasikan tentang kejarlah dalam pencarian di dunia ini hingga sampai derajat jiwa yang tenang dan tidak hanya berhenti hanya tentang iman.

Hamka dalam kitabnya Tafsir AlAzhar (2015, jilid 1, p. 287) menafsirkan QS. Al-Baqarah [2]:153 bahwa apakah yang engkau takutkan kepada hidup ini kalau Allah telah menjamin bahwa Dia ada beserta engkau? Orang yang ditimpa oleh suatu 
percobaan yang membuat jiwa jadi gelisah kemudian berpegang teguh kepada ayat ini, membenteng diri dengan sabar dan shalat, dengan berangsur timbullah fajar harapan dalam hidupnya. Kelihatan dari luar dia dalam kesepian, padahal dia merasa ramai sebab dia bersama Allah. Belenggu biar di pasang pada tangannya, tetapi jiwanya merasa bebas. Pagar besi membatasi jasmaninya dengan dunia luar.

Menurut analisa penulis, QS. AlBaqarah [2]:153 ayat ini menjelaskan tentang apabila seseorang mukmin menghadapi kesulitan, maka ada hal yang harus dipegang yaitu kesabaran dan istiqamah serta shalat dan hubungan dengan Allah.

\section{Membantu Manusia dalam Menjaga Kelangsungan Hidup}

Ayat dan Terjemahan

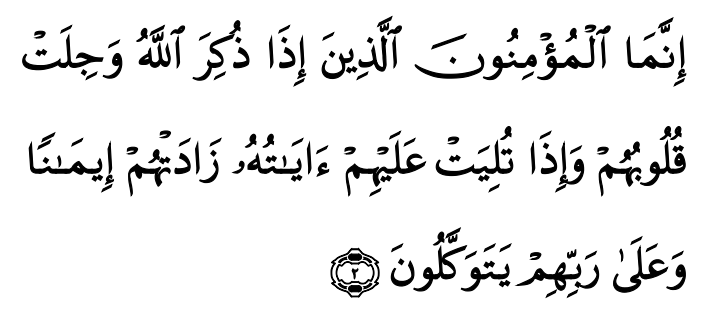

Artinya: Sesungguhnya orang-orang yang beriman ialah mereka yang bila disebut nama Allah gemetarlah hati mereka, dan apabila dibacakan ayatayat-Nya bertambahlah iman mereka (karenanya), dan hanya kepada
Tuhanlah mereka bertawakkal (QS. AlAnfal [8]:2)

Hamka dalam kitabnya Tafsir AlAzhar (2015, jilid 3, p. 663) menafsirkan QS. Al-Anfal [8]:2 bahwa kata innama, huruf itu dalam kuasa artinya dalam bahasa Arab dinamai alat pembatas. Sebab itu, arti yang agak tepat dalam bahasa Indonesia ialah "tidak lain", atau "cuma", atau "hanyalah" di sini diartikan "sesungguhnya". Kalau ada orang yang mengakui dirinya beriman menurut ayat ini, belumlah diterima iman itu dan belumlah terhitung ikhlas, kalau hatinya belum bergetar mendengar nama Allah disebut orang. Apabila nama itu disebut, terbayanglah dalam ingatan orang yang beriman itu betapa maha besarnya kekuasaan Allah, mengadakan, menghidupkan, mematikan dan melenyapkan.

Lebih lanjut Hamka dalam kitabnya Tafsir Al-Azhar (2015, jilid 3, p. 664) menafsirkan QS. Al-Anfal [8]:2 bahwa bertawakal artinya ialah berserah diri. Imam Syafi'I, Imam Ahmad Bin Hanbal dan Imam Abu 'Ubaid mengartikan bertawakal kepada Allah itu ialah tidak berharap kepada yang lain, dan tidak berserah diri atau menyerahkan segala untung nasib dan 
pekerjaan yang lain. Tawakal di sini tentu saja tidak sekali-kali mengabaikan ikhtiar. Karena sekali takut mendengar nama-Nya disebut, niscaya dibuktikan rasa takut itu dengan rasa kepatuhan melaksanakan yang diperintahkan dan menjauhi yang dilarang. Kalau sudah bertawakal kepada Allah niscaya lebih lagi mempercayai bahwa segala perintah yang diturunkan Allah kepada manusia, mustahil akan membawa celaka manusia

Menurut analis penulis, QS. AlAnfal [8]:2 ayat ini menjelaskan bahwa orang-orang beriman adalah mereka yang takut kepada Allah karena keagunggan dan kemuliaan-Nya, dan ketika ayat-ayat al-Quran yang dibacakan itu mengenai keadilan Allah, hukuman dan ketentuan-Nya, mereka merasa ngeri dan bergetarlah hati mereka. Ketika dibacakan ayat-ayat mengenai kemurahan, kasih sayang, rahmat dan pahala Allah, mereka merasakan ketentraman dalam diri mereka dan bertambah keimanan mereka. Ayat ini juga menginformasikan bahwa orang-orang beriman itu mereka senantiasa bertawakal hanya kepada Allah dalam berbagai keadaan apapun dan menggantungkan diri kepada-Nya mengenai segala urusan dalam hidupnya.

\section{KESIMPULAN}

Hasil penelitian ini menyimpulkan bahwa secara umum ada tiga pengaruh shalat terhadap kesehatan mental menurut ulama tafsir yaitu: (a) Pengaruh shalat terhadap pikiran menurut Buya Hamka ada 2 yaitu pengaruh besar yang dikandung oleh shalat terhadap pikiran (QS. Hud [11]:56, QS. Ar-Ra`d [13]:22, QS. AlIsra [17]:78) dan shalat dapat menambah kekuatan jiwa dan meringankan beban yang dipikul (QS. Ar-Ra'du [13]:28 dan QS. An-Nisa [4]:103), (b) Pengaruh shalat terhadap emosional menurut Buya Hamka ada 2 yaitu membina serta membiasakan jiwa agar terhindar dari sifat tercela (QS. Al-Baqarah [2]:153, dan QS. Al-Fajr [89]:27-28) dan membantu manusia dalam menjaga kelangsungan hidup, serta aman dari emosi takut dalam kehidupan. Contohnya takut kepada siksaan Allah (QS. Al-Anfal [8]:2), (c) Pengaruh shalat terhadap spiritual ada 2 yaitu keutamaan terbesar dalam segi 
spiritual (QS. Al-Baqarah [2]:45 dan QS. Al-Ma'arij [70]:34-35) dan shalat sebagai terapi pengobatan yang efektif bagi jiwa (QS. Al-Ankabut [29]:45, QS. Al-'Ala [87]:15 dan QS. AlBaqarah [2]:3)

\section{REFERENSI}

Amril, D., \& Hafizzullah, H. (2020). KONSEP MAKAR DAN CARA MENGATASINYA DALAM PERSPEKTIF AL QUR'AN. Al FAWATIH: Jurnal Kajian Al Quran dan Hadis, 1(1), 31-46.

Astuti. (1982). "Jurnal Konsep Ruh Dalam Perspektif Psikologi Pendidik Barat dan Islam" dalam Fenomena Vol. 7, No. 2, 2015

al-Arid. A. H. (1994). Sejarah dan Metodelogi Tafsir. Terjemahan. Akrom. A. Tarikh Ilm At-Tafsir wa Manahaj al-Mufassirin. Jakarta: Raja Grafindo

Basyarahil. S. (1996). Hikmah Shalat, Falsafah dan Urgensinya. Cet 1. Jakarta: Gema Insani Pres

al-Baqi, M.F. (1981). Mu`jam AlMufahras li Alfaz Al-Quran AlKarim. Dar Al-Fikr. Beirut

Burhanuddin, Y. (1999). Kesehatan Mental. Bandung: CV. Pustaka Setia.

Darajat, Z. (1982). Pendidikan Agama dalam Pembinaan Mental. Jakarta: Bulan Bintang.

Darwis. (2006). Emosi Penjelajahan Religio Psikologis tentang Emosi Manusia dalam alQuuran. Jakarta: Erlangga
Dewi. S. K. (2012). Buku Ajar Kesehatan Mental. Semarang: CV Lestari Media Kreatif

Efendi, Y. (2011). Praktek Shalat Ala Rasulullah Sebuah Upaya Menapaktilasi Warisan Sunnah. Batusangkar: Batusangkar Prees.

Firdaus. (2016). "Spritualitas Ibadah Sebagai Jalan Menuju Kesehatan Mental" dalam AlAdyan Vol. 1 No. 5, JanuariJuni

Fitriasari, R. (2019). Kesehatan Jiwa. Jakarta: Mitra Wacana Media

Hadi, M, K. (2014). "Karakteristik Tafsir Al-Maraghiy dan Penafsirannya tentang Akal" dalam Hunafa: Jurnal Studia Islamika Vol. 11, No. 1, Juni

Hafizzullah, H., Ismail, N., \& Ulya, R. F. (2020). Tafsir Lathâif alIsyârât Imam al-Qusyairy: Karakteristik dan Corak Penafsiran. Jurnal Fuaduna: Jurnal Kajian Keagamaan dan Kemasyarakatan, 4(2), $\quad$ 147159.

Hasan, L. (1992). Teori-teori Kesehatan Mental. Jakarta: Pustaka al-Husna

Hamka. (2015). Tafsir Al-Azhar. Jakarta: Pustaka Panjimas

Hawari, D. (1996). al-Quran Ilmu Kedokteran Jiwa dan Kesehatan Jiwa. Jakarta: Dana Bhakti Prima Yasa.

Hilmi, K. (2007). Mukjizat Kesehatan Gerakan Shalat. Jogjakarta: Hikam Pustaka.

Jalal, S. (2009). Dahsyatnya Gerakan Sholat. Jakarta: Gema Insan.

Julifa, M. T., \& Hafizzullah, H. (2020). IMPLEMENTASI MASYARAKAT TERHADAP PENAFSIRAN SURAT AL- 
QADR. Alfuad: Jurnal Sosial

Keagamaan, 4(1), 1-11.

Mujiburrahman. (2016). "Pola

Pembinaan Keterampilan Shalat

Anak Dalam Islam" dalam

Jurnal Mudarrisuna Vol. 6, No.

2, Desember

Napitupulu. (2019). "Elemen-elemen Psikologi dalam Al-Quran" dalam Psikoislamedia Jurnal Psikologi Vol. 4, No. 1, 2019

Rifa'i. (2010). Risalah Tuntunan Shalat Lengkap. Semarang: Karya Putra Thoha

Saifuddin, M, H. Studi Tokoh Tafsir dari Klasik Hingga Kontemporer.Pontianak: IAIN Pontianak Press

Shidqiy, N. (1986). Nikmat Al-Quran Cet 1. Terjemahan Hery Noer Aly. Husaini Bandung: Bandung

Shiddiqi, N. (1997). Fiqih Indonesia. Pustaka Pelajar: Yogyakarta

Shihab, M. Q. (2002). Tafsir Al-Misbah Pesan Kesan dan Keserasian al-Qur'an. Jakarta: Lentera Hati.

Sjaroni. (2014). Studi Tafsir Tematik. Jakarta: Panca Wahana.

al-Suyuthi, J. (2006). Terjemahan Tafsir Jalalain Berikut Azbabun Nuzul. Sinar Baru Algensindo: Bandung

Thalba, H. (2010). Ensiklopedia Mu'jizat al-Quran dan Hadits . ttp: Perpustakaan Nasional RI.

al-Turmudzi. (1998). Sunan alTurmudzi Naskah di Tahqiq oleh Bayar Awwad Ma`ruf. Beirut: Dar al-Ghurb al-Islami

Thaib, H. (2006). Pemikiran dan Karya Monomental Kesehatan. Medan: Pustaka Bangsa Pres

Ulya, R. (2020). Konsep Jihad dalam Tafsir Al-Maraghi (Studi Tafsir
Tematik Tentang Jihad dalam QS. At-Taubah). Ishlah: Jurnal Ilmu Ushuluddin, Adab dan Dakwah, 2(2), 274-303.

Zed, M. (2004). Metode Penelitian Kepustakaan. Jakarta: Yayasan Obor Indonesia.

al-Zayn, S, R, M. Al-Mu`jam AlMufahras Li Ma`ani Al-Quran Al-Azhim Cet 1. Beirut: Dar AlFikr Al-Mu`ashir 